\title{
Obituary
}

\section{ROGER YATE STANIER, 1916-1982}

It was with sadness and a sense of grievous loss that microbiologists the world over learned of the death of Roger Stanier on 29 January 1982. He had courageously fought, but had eventually succumbed to, a cancer that had been diagnosed some years earlier and had been countered by a succession of operations. Each was bravely borne and each had been the prelude to a convalescence in which he displayed all of the determination, combative spirit and realism that had marked his scientific life.

His decision to embark on a career in microbiology had been (on his own admission) the result of certain compromises between his own interests and his father's wish that Roger should follow him into medicine. However tentatively he may have embarked on his life's work, by his skilful and timely researches, by his ability to recognize and then tease out basic principles from a tangled mass of seemingly unrelated findings and, above all, by his articulateness in expressing his views, he influenced a whole generation of microbiologists.

Roger Yate Stanier was born in 1916 in Victoria, British Columbia. His parents were immigrant British 'gentry' and the young Roger Stanier was very aware of the stratification which divided this minority from the democratic and egalitarian native Canadians who formed the majority of the inhabitants of that attractive provincial capital. He was to remain proud of his Canadian heritage, choosing to retain his nationality despite his living for the most part abroad in the USA and France. Indeed, in the second World War, he was voluntarily to return to Canada to aid in its war effort by participating in useful applied microbiological projects among them production of 2,3-butanediol by fermentation, and large-scale production of penicillin. In his account of these years (Stanier, 1980) he typically made no reference to his reasons for quitting the US for Canada at a crucial period in his career. It was, in fact, the outcome of much heart searching and was impelled by his detestation of fascism and his abiding commitment to the liberty of the individual and the basic freedoms of opinion and speech. Whilst these beliefs had been consolidated as the result of his visit to Germany in the 1930 s, his manifest dislike of cant and humbug, and his abhorrence of pretentiousness in whatever form, probably dated from his experiences in childhood.

His father had studied medicine at the University of Toronto and, himself an innovator, had established the first private practice of diagnostic radiology in western Canada in the early years of that new science. His mother was a teacher relatively newly arrived from England, and was unusually well educated for a young lady of the time, having read English Literature at Cambridge. Possibly Roger's own abiding love of books and of good writing was his mother's gift to him, though he himself was to state that two talented teachers in Victoria College taught him all the English he knew. Following a severe illness in his pre-school years, his health was a matter of some concern to his parents who placed him, at the age of seven, in a local private boarding school. From here he was moved at nine years of age to an establishment largely staffed by imported British teachers. In this 'resident penal colony' he was desperately unhappy, finding the regime barbarous and unmitigated by any pretensions to scholarship. His experiences therein, together with the increasingly authoritarian attitude of his father, contrived to induce in him a deep sense of inadequacy which was to remain with him, leaving him 'drained of selfconfidence' until in C. B. van Niel he found the mentor capable of persuading him that he could hope to 'amount to something'.

His real education began in the local junior college, from which he emerged with a preference for literature and history but also with an enthusiasm for biology which had been taught him, with passion, by a classical zoologist dedicated to rigorous and precise observation and experimentation. Subsequently entering the University of British Columbia (UBC), he read 
bacteriology, graduating with first-class Honours in 1936 . He was later to say that chemistry was atrociously taught both in Victoria College and in UBC, and he always regretted that he had received an inadequate training in the physical sciences. Although aware of what he considered to be this weakness, he was not deterred from tackling problems of metabolism and enzymology that would have proved challenging to the best trained of biochemists. In these ventures he had the percipience and good fortune to collaborate with colleagues whose skills complemented his own, as was the case when he and Osamu Hayaishi worked together on aspects of tryptophan metabolism, or again when he encouraged the young Synnøve Liaaen-Jensen to undertake a careful analysis of the very complex interconversions of the carotenoid pigments in Rhodospirillum rubrum. It was in an attempt to remedy his deficiency in chemistry that, following his graduation, he first repaired to Europe - to the University of Munich. But this was 1936 and National Socialism was in the ascendancy in Germany. He was both shocked and made despondent by what he found in Munich, gave up his intention to study, and instead travelled for several months through what he considered to be a doomed Europe. Returning briefly to a graduate student placement in the University of California, Berkeley, he then accepted a teaching assistantship in the sister campus of the University of California in Los Angeles (UCLA).

The watershed experience, which decided him on his career and which gave him the enthusiasm and self-confidence to embark upon it, was his enrolment in the summer course of 1938 taught by C. B. (Kees) van Niel at the Hopkins Marine Station, Pacific Grove. All those who were privileged to attend any of these annual courses were to fall under van Niel's spell. The lectures were absorbing, not the least because of their almost theatrical quality, but also because they were exceptionally well crafted and documented. The practical sessions were lessons in keen observation, clear reasoning and the art of drawing defensible conclusions. All of this activity was perfused throughout by van Niel's love of micro-organisms, his old-world charm, and his gentle insistence on the highest professional standards of scientific enquiry. Roger Stanier found the combination irresistibly inspiring: 'It took less than a week to conclude that van Niel was the ideal master and teacher; general microbiology was to be my domain'. Thus was started that special relationship between elder statesman of science and brilliant protégé that was to be the source of much strength to Roger and of pleasure to them both as the ties of discipleship became gradually replaced by the still stronger bonds of mutual affection and respect. That summer was also to be notable for first bringing Roger Stanier to the attention of Mike Doudoroff, who was serving as teaching assistant on the van Niel course. We have Roger's account of that meeting: 'I recall that he dashed in and out of the classroom in buccaneer style, a black eyepatch well fitting his Armenian features. He was then engaged in the isolation of "dim" mutants of luminous bacteria and couldn't spare the time to get dark-adapted'. It would, however, be interesting to have had recorded Doudoroff's early impression of the young Canadian in that class of five, probably somewhat withdrawn at first but becoming increasingly excited as he glimpsed the wondrous new world of general microbiology through which he was being escorted. It was a wonder that never left Roger and that he was fortunately able to convey to all of his future pupils and, via his writings, to a much larger constituency.

On his return to UCLA, Roger Stanier studied marine agar-decomposing bacteria, but eagerly returned to Pacific Grove in the summer of 1939 . Here he spent three exceptionally happy and rewarding years during which he worked with a variety of cellulose- and agardecomposing microbes, including cytophagas, chytrids and streptomycetes. His return to Canada in 1942 was a maturing interlude, but it was with relief that in 1945 he accepted a Guggenheim Fellowship to work in Marjory Stephenson's laboratory in Cambridge. He must have had high hopes indeed of that visit; his wish, yet again, to improve his knowledge of biochemistry was probably fortified by tales related by his mother of that ancient University as a fount of culture as well as of distinguished science. It is evident that he was personally disappointed by what he found there. Perhaps, with Britain only just emerging from the traumas of the war, life in an unusually austere Cambridge with its shortages of food and fuel was less than attractive to a visitor from North America. More probably, he found in Cambridge much that he had resented in the gentility of Victoria, BC, together with a certain 'stand-offishness' 


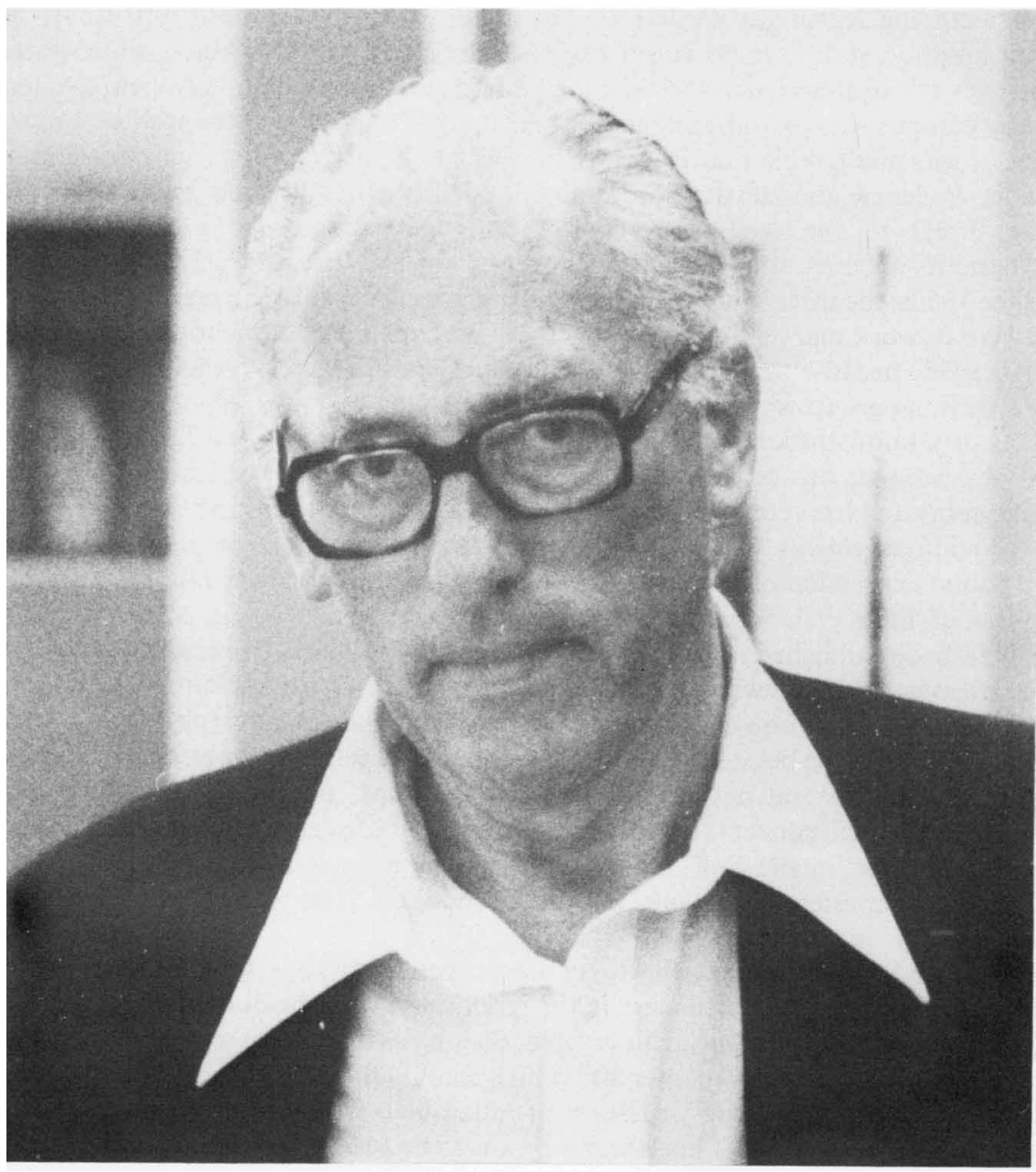

ROger Yate Stanier

which, at least, had the welcome consequence of cementing a valued friendship with another lonely visitor to the University, namely E. G. Pringsheim, the celebrated algologist. Although Roger enjoyed, and was to retain, the friendship of established members of the Department of Biochemistry in Cambridge, such as Ernest Gale, he chose to spend the latter half of his Fellowship at the Rothamsted Experimental Station. Here he continued his studies of cytophagas, isolating and characterizing the chitinolytic Cytophaga johnsonae, and finding the relatively tranquil laboratory much more in tune to his needs.

His return to California was via a one-year appointment in the University of Indiana, but it was with delight that he found himself once again in the University of California, Berkeley, with Mike Doudoroff now as a colleague. Their role was to strengthen the non-medical aspects of the teaching and research programme of the Department of Bacteriology and to this end they were joined (in 1949) by Ed Adelberg, appointed as a biochemical geneticist. The years in Berkeley, which were to extend from 1947 to 1971, encompassed the bulk of Roger Stanier's research, teaching and writing. He was to become very attached to the University and was always concerned that it should sustain its exceedingly high reputation for scholarship. He was outspoken in defence of its freedoms, whether these were under assault from without or, more insidiously, were in danger of being eroded from within. On matters of principle, his articulateness and disdain for bureaucratic dissembling made him a powerful opponent and 
some who were the legitimate targets of his ire did not always yield gracefully. Yet his transparent honesty, and his concern for truth and integrity, won for him a wide spectrum of staunch friends amongst his colleagues and the high regard of the students. When, in later years, the Berkeley campus was to find itself in the vanguard of student protest and the Free Speech Movement, it was predictable that Roger Stanier was to be deeply hurt when this degenerated into random violence and destruction. Indeed, so dispirited was he by this, and by the impending threat to the well-being of the University posed by a State Government unsympathetic to its aims, that he quitted Berkeley for the Institut Pasteur in Paris.

During the 1950s, the three senior non-medical members of the Department of Bacteriology in Berkeley were to work marvellously well together. Perhaps they complemented each other the more productively because they were so disparate in their characters. Adelberg, in addition to directing a thriving group of young bacterial geneticists, in his quiet efficient style shouldered the burdens of administration for the triumvirate. The unconventional Doudoroff who, as a microbial physiologist, was possessed of that greatest of all gifts, experimental flair, provided the kinetic energy and irreverence for shaky dogmas. Stanier served as the lynch-pin member of the trio, providing gravitas when required, inspiration seemingly on demand, and giving articulate public expression of their views, especially to the University administration. It was the closeness of their collaboration that ensured the success of their co-authorship of the celebrated textbook published in 1957 in the USA as The Microbial World and, later, in the UK as General Microbiology. This was a tremendous achievement, for it was immediately recognized to have fulfilled their chief aim of presenting 'a modern synthesis of microbiological knowledge in a form intelligible to the beginner'. What was particularly refreshing about this work was that it discussed the nature and activities of micro-organisms, not in isolation, but against a background of biological concepts equally relevant to other life forms. As they explained in their note 'To The Reader' in the first edition, 'one can be a good biologist without necessarily knowing much about micro-organisms, but one cannot be a good microbiologist without a fair basic knowledge of biology'.

To those who did not know him well, Roger Stanier could appear a rather aloof and forbidding figure. He was indeed a hard task master in the laboratory, since he did not tolerate fools gladly and set high standards of scientific achievement. So long as one strove to attain those standards he was the enthusiastic and helpful mentor, exhilarated by the novel observation and still more by the disclosure of some new principle of microbial structure or behaviour. In these circumstances, to be a member of his laboratory was to be accepted into a warm family wherein one felt it possible to attempt anything (within reason). He inspired affection and great loyalty in his assistants by whom he was, consequently, well served. In turn he was always quick to recognize their expert contributions; the work of Riyo Kunisawa and of Rosmarie Rippka particularly earned his praise and gratitude. Though his own description of his research work (Stanier, 1980) modestly underestimates the impact of much that he accomplished, this summary provides a fascinating account of how he was led from one problem to another. It also encourages his successors by the fact that serendipity and the occasional arid patch played as much a part in his research career as in that of any other successful scientist.

Even to summarize Roger Stanier's major contributions causes one to marvel at his breadth of vision and accomplishments. Following his early work on the degradation of agar, chitin and cellulose, and his spell of large-scale applied microbiology in wartime Canada, he bravely tackled the problems posed by the dissimilation of aromatic compounds by fluorescent pseudomonads, despite his qualms about his biochemical ignorance. From these studies emerged the principle of 'simultaneous adaptation' and, with the help of various colleagues, he went on to amass a great deal of information concerning the nature of the intermediates and enzymes implicated in the $\beta$-ketoadipate and protocatechuate pathways, being eventually concerned with the means whereby these pathways were regulated in various species and genera of bacteria. During the tenure of a second Guggenheim Fellowship in 1951-2 he worked with I. C. Gunsalus on the mechanism of oxidation of mandelate, but by this time he had already collaborated with Howard Schachman and Arthur Pardee in the ultracentrifugal analysis of cellfree extracts of various bacteria which first revealed the existence of ribosomes. One extract so 
examined was of the purple non-sulphur bacterium Rhodospirillum rubrum, and it came as a major surprise to find that the photosynthetic pigments of this bacterium were apparently localized in sub-cellular, particulate structures - to be termed chromatophores. Although these structures were eventually to turn out to be no more than vesicles arising from the comminution of the cell membrane, the stage was set for a productive examination not only of the kinetics of photopigment synthesis in purple non-sulphur bacteria but also of the means whereby this synthesis was regulated. In this study he was joined by Germaine Cohen-Bazire, whom he had first met whilst spending the end of his sabbatical year of 1951-52 working with Jacques Monod in Paris. They married in 1956 and thereafter Germaine was to remain not only his much loved wife and confidante but also his constant colleague in the laboratory, a stabilizing and quietly inspiring influence upon all his works. Those who had known Roger Stanier both before and after his marriage used to remark on 'how he had mellowed'. In truth he had found, somewhat later than some, satisfaction and contentment in his domestic life as well as a companion scientist whose views he valued most highly, whose humour he much appreciated, and from whom he drew much strength. Their marriage brought to him a stepson, Henri, of whom he became very fond and additionally proud when he turned out to be a gifted mathematician. The birth of his daughter, Janie, was a source of great joy and happiness and he took particular interest in her education - possibly to ensure that she would not have to experience anything similar to the traumatizing school years that he had endured.

Work on the photosynthetic bacteria proceeded apace, with very significant findings being made on the nature and role of the carotenoid pigments and on the role of organic substrates in photoheterotrophy. Those were exhilarating days in photosynthesis research in Berkeley. Melvin Calvin's group was hard at work in the basement of the Life Sciences building tracing the reduction of carbon dioxide in algal photosynthesis. On the third floor of the same building Daniel Arnon's group was wrestling with the problems posed by the transduction of incident light energy into the chemical potential of ATP, using amongst other experimental organisms the purple sulphur bacterium Chromatium as a source of photophosphorylating membrane preparations. Simultaneously, but on the fifth floor, Roger and Germaine were investigating the pathways of photoassimilation of organic compounds supplied to purple non-sulphur bacteria.

An impressive attribute of Roger Stanier as a supervisor was that he did not dragoon his graduate students into participating in what was currently his own major research interest. Instead, he sought to encourage their personal initiatives, thereby forcing himself to retain an unusual breadth of interests. Thus, at the same time that he was immersed in work on anoxygenic photosynthetic bacteria, he was supervising Charles Spott's study of streptomycin dependence in mutant strains of $E$. coli and encouraging Jeanne Stove (later Poindexter) in what was to prove a classic study of the Caulobacter group of stalked bacteria. He himself scarcely hesitated to embark on a study of Pseudomonas taxonomy that many others would have considered no less than a life's work. With the collaboration of Mike Doudoroff and Norberto Palleroni he was eventually to accumulate a collection of some thousand cultures of Pseudomonas, and the authoritative monograph that they published in 1964 contained detailed descriptions of about 270 of these, particular use being made of biochemical characters that had not previously been widely employed in the classification of this group of bacteria. Despite finding that this was a long and laborious enterprise, he was not deterred when later he was to be faced with the need to undertake an equally detailed, and eventually even more influential, taxonomic study of the cyanobacteria.

When, in 1971, Roger Stanier left Berkeley for the Institut Pasteur he was, so he said, disillusioned with academic life. The prospect of attachment to a purely research institute was particularly attractive to him, especially when it had been agreed that Germaine and he could devote themselves entirely to a study of the cyanobacteria. And what a profitable period the next few years proved to be, when with colleagues (especially Michael Herdman and Rosmarie Rippka) much fundamental work was undertaken on the structure, physiology and taxonomy of these oxygenic photosynthetic bacteria. The reclassification of these prokaryotes was pursued in the face of initial resistance by many phycologists, who were reluctant to modify taxonomic schemes which had been constructed according to the provisions of the Botanical rather than the 
Bacteriological Code. In retrospect, it was fitting that Roger Stanier's final major expedition amongst the microbes should have been amongst a relatively neglected group of prokaryotes, for as soon as they became the focus of his attention it was certain that they would yield up many of their secrets and that other workers would be inspired to follow the trails that he had blazed. It was further fortunate that to this culminating study of the cyanobacteria he could bring the wealth of experience gained by his work on anoxygenic photosynthetic bacteria and by his essays in taxonomy.

In his autobiographical notes (Stanier, 1980) he reflected that it was possible that he had skated somewhat lightly and superficially over what later proved to be major problems of molecular biology. He went on to say: 'But that's the inevitable penalty paid by foxes, who like to skim the cream off a diversity of promising subjects, and not be hedgehogs, who labor patiently over one big topic through decades'. In his likening of himself to a fox rather than a hedgehog, he was making oblique reference to a line written by the Greek poet Archilochus which says: 'The fox knows many things, but the hedgehog knows one big thing'. Isaiah Berlin wrote a distinguished essay on Tolstoy's view of history which he entitled 'The Hedgehog and The Fox', in which he offered the hypothesis that Tolstoy was by nature a fox but believed in being a hedgehog. It may be that Roger Stanier, contrariwise, was a hedgehog masquerading as a fox, for although he was profligate with ideas and seemingly casual in his choice of research topics, the main thrust of his work was centripetal rather than centrifugal; not so diffuse after all, but constantly bearing on the recurrent theme 'What is a Prokaryote?'. Certainly this preoccupation with the salient features of the prokaryotes ran like a leitmotif through his writings. Indeed, at the outset he considered it 'one of the intellectual scandals of general microbiology' that there was no clear definition of the bacteria. In the course of his career he helped to establish the characteristics of prokaryotes and was prepared to speculate on the nature of the major evolutionary discontinuity which separated prokaryotes and eukaryotes. Yet whenever he felt that he was in danger of waxing too philosophical or of verging on the pompous and didactic, he would counter the tendency with wry humour and some deflatory comment. One of my favourite passages occurs in his contribution to the 20th Symposium of the Society for General Microbiology, which he entitled 'Some Aspects of the Biology of Cells and their Possible Evolutionary Significance': 'It might have happened thus; but we shall surely never know with certainty. Evolutionary speculation constitutes a kind of metascience, which has the same intellectual fascination for some biologists that metaphysical speculation possessed for some mediaeval scholastics. It can be considered a relatively harmless habit, like eating peanuts, unless it assumes the form of an obsession; then it becomes a vice.'

He was a skilful manipulator of Occam's razor, always being on the lookout for the 'unifying hypothesis' or 'the simplest common denominator'. Such reductionism occasionally caused him to underestimate the complexities of certain phenomena, obligate autotrophy for example; more frequently, it granted him a clear insight into microbial behaviour and interrelations, which was denied those who were more easily distracted by trivial detail.

To his friends it appeared that in France, where he lived in the country just south of Paris, he had found his spiritual home. Although his chief preoccupation remained his scientific work, he took pleasure in his English garden, in books and reading, in his family and friends. He had retained a summer retreat in British Columbia (on Hornby Island) and the regular visits which he and Germaine made there he deemed to be recuperative.

Roger Stanier served the Society of General Microbiology as an esteemed member of its Council and was elected to Honorary Membership in 1978. His contributions to science were recognized by the award to him of so many honours that only a representative few can be mentioned. He served as Prather Lecturer at Harvard University and as Storer Lecturer at the University of California, Davis. In 1976, he was named Emil Christian Hansen medallist of the Carlsberg Foundation in Copenhagen and was elected a Scholar of the Royal Academy of Arts and Sciences of the Netherlands, which later presented him with its Leeuwenhoek Medal. In 1977 he was awarded the Legion d'Honneur in a ceremony made the more memorable by his being kissed on both cheeks by André Lwoff, 'an experience not given to everyone'. He was elected a Foreign Associate Member both of the National Academy of Sciences of the USA and 
of the French Academy of Sciences. On the occasion of his election in 1978 to Fellowship of the Royal Society, he no doubt took particular pleasure in joining that Society to whom van Leeuwenhoek first communicated his discovery of the microbial world. All of these honours sat lightly upon him. He was a distinguished and cultured man of science, an inspirational teacher, a general microbiologist in the van Nielian tradition; and so he would have had us remember him.

Stanier, R. Y. (1980). The journey, not the arrival, matters. Annual Review of Microbiology 34, 1-48.

J. GARETH MORRIS 